\title{
PERANCANGAN TATA LETAK MESIN DENGAN MENGGUNAKAN KONSEP GROUP TECHNOLOGY SEBAGAI UPAYA MINIMASI JARAK DAN BIAYA MATERIAL HANDLING
}

\author{
Eti Kristinawati ${ }^{1}$
}

\section{ABSTRACT}

PT. Berlina Tbk Pandaan is a company that produce already use plastic product package. Some of its product are Nivea bottle, Lux shower bottle, packaging of sheats and the other form variation. The processing to make it, need at least twice a process of machine. All those product through some operation which happened a long way material handling from one machine to another. As main product facility is through the the machine layout can be seen that machine placement still arbitrarily, and it will cause product current longer so that cost and distance fo rmaterial handling also bigger.

To solve this problem, we have to study a theory group technology. Major point $f$ this theory is machine grouping become machine cell also product grouping become part family so that, later, each machine cell will produce a certain of part family according certain criteria. With the computer program called gtlaypc.exe, part family and machine cell can be know and use it for planning a machine layout.

The result of machine layout planning using group technology is total distance $27853,5 \mathrm{~m}$ per day and $18978 \mathrm{~m}$ per day smaller from the earlier exiting machine layout so that the cost of material handling plan Rp. 35109,3 per day more smaller. Planning the machine layout with the group technology can minimalize of cost and distance material handling

\section{Key Words : layout, group tehcnology, material handling}

\section{PENDAHULUAN}

Tata letak pabrik adalah suatu landasan utama dalam dunia industri. Tata letak pabrik (plant layout) atau tata letak fasilitas (facilities layout) merupakan tata cara pengaturan fasilitas-fasilitas pabrik seperti gedung sebagai fasilitas utama maupun fasilitas produksi lainnya, guna menunjang kelancaran proses produksi.

Dalam kasus ini, kami mengambil studi kasus di PT. Berlina Pandaan. PT. Berlina adalah salah satu perusahaan manufaktur yang memproduksi berbagai macam bentuk produk siap pakai dari bahan plastik. Dalam memproduksi, perusahaan ini berdasarkan pesanan sehingga variasi bentuk produk sering berubah. Dengan variasi produk yang banyak tersebut, akan diperlukan proses permesinan yang fleksibel (mudah menyesuaikan perubahan variasi produk), maka pengaturan tata letak mesin lebih tepat menggunakan konsep Group Teknologi, dimana tata letak mesin akan diatur sesuai dengan kesamaan komponen dalam proses pembuatan atau perancangan.

Pada umumnya, aktifitas produksi suatu industri secara manualnya akan berlangsung lama dengan tata letak yang tetap, maka setiap kekeliruan yang dibuat 
dalam perencanaan tata letak ini akan menyebabkan beberapa kerugian, misalkan saja besarnya jarak dan biaya dalam proses pemindahan bahan. Berdasarkan survey kami yang kami lakukan pada departemen blow molding, yaitu departemen yang memproduksi produk kemasan siap pakai, contohnya : kemasan shampoo, kemasan sarung, botol Nivea, botol permen serta masih banyak produk lain, terjadi jarak tempuh yang panjang dalam proses pemindahan bahannya, akibat dari peletakan mesin yang sembarangan. Melihat kenyataan tersebut, sebaiknya dilakukan sebuah kajian teori mengenai perancangan tata letak mesin agar pola material handling bisa diatur, sehingga meminimalkan jarak dan biaya material handling.

\section{LANDASAN TEORI}

\section{Macam atau Tipe Tata Letak Pabrik}

Untuk menetapkan prosedur atau metode pengaturan tata letak dari fasilitas-fasilitas produksi tersebut, ada empat macam tipe tata letak yang umum diaplikasikan dalam desain layout, yaitu :

a. Tata letak fasilitas berdasarkan aliran produksi (Production line product atau Product layout)

b. Tata letak fasilitas berdasarkan lokasi material tetap (Fixed material location product lay out atau fixed position lay out)
Untuk tata letak pabrik yang berdasarkan proses tetap, material atau komponen produk yang utama akan tinggal tetap pada posisi/lokasinya.

c. Tata letak fasilitas berdasarkan kelompok produk family (Product family, product lay out atau group technology)

Tata letak tipe ini didasarkan pada pengelompokan produk atau komponen yang akan dibuat. Produk-produk yang tidak identik dikelompokkan berdasarkan langkah-langkah pemrosesan, bentuk, mesin atau peralatan yang dipakai dan sebagainya.

d. Tata letak fasilitas berdasarkan fungsi atau macam proses (Functional atau process lay out)

Tata letak tipe ini didasarkan pada pengaturan dan penempatan dari segala mesin serta peralatan produksi yang memiliki tipe/jenis sama ke dalam satu departemen.

\section{Pola Aliran Bahan Untuk Proses Produksi}

a. Straight Line

Pola aliran berdasarkan garis lurus atau straight line umum dipakai bilamana proses produksi berlangsung singkat, relatif sederhana, dan umumnya terdiri dari beberapa komponen-komponen atau beberapa macam production equipment. 
b. Serpentine atau Zig-zag (S-Shape)

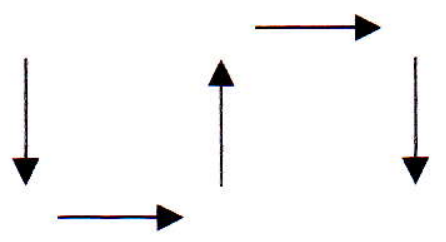

d. Circular

Pola aliran berdasarkan garis patahpatah ini sangat baik diterapkan bilamana proses produksi lebih panjang dibandingkan dengan luasan yang tersedia.

c. U-Shape

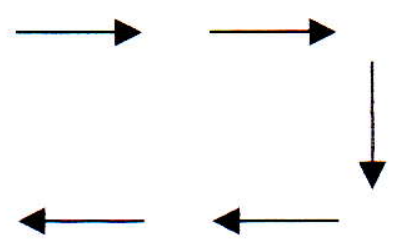

Pola aliran menurut U-Shape akan dipakai bilaman dikehendaki akhir dari proses produksi akan berada pada lokasi yang sama dengan awal proses produksinya.

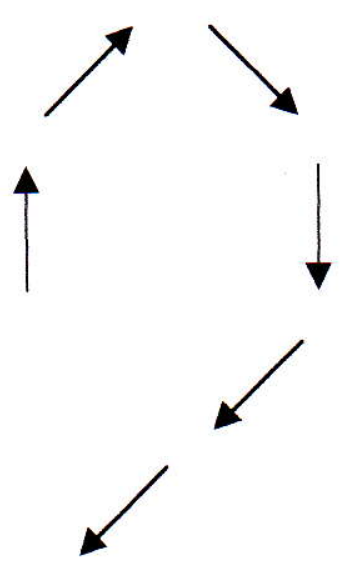

Pola ini sangat baik digunakan bila dikehendaki untuk mengembalikan material atau produksi pada titik awal aliran produksi berlangsung.

e. Odd Angel

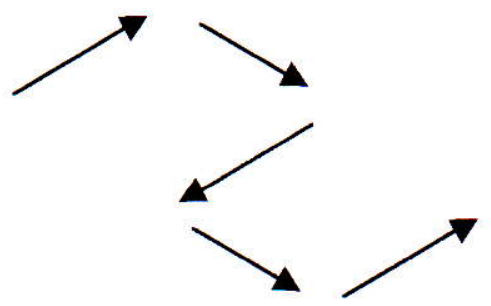

Peta Proses Untuk Menganalisa Aliran Bahan

\begin{tabular}{|c|c|l|}
\hline SIMBOL ASME & NAMA KEGIATAN & \multicolumn{1}{|c|}{ DEFINISI KEGIATAN } \\
\hline & OPERASI & $\begin{array}{l}\text { Kegiatan ini terjadi bilamana sebuah obyek mengalami } \\
\text { perubahan bentuk, baik secara fisik atau kimiawi }\end{array}$ \\
\hline & INSPEKSI & $\begin{array}{l}\text { Kegiatan ini terjadi bila sebuah obyek mengalami pengujian } \\
\text { ataupun pengecekan dari segi kuantitas atau kualitas }\end{array}$ \\
\hline & TRANSPORTASI & $\begin{array}{l}\text { Kegiatan ini terjadi bila sebuah obyek dipindahkan dari satu } \\
\text { lokasi ke lokasi lain }\end{array}$ \\
\hline & $\begin{array}{c}\text { MENUNGGU } \\
\text { (DELAY) }\end{array}$ & $\begin{array}{l}\text { Kegiatan ini terjadi bila benda kerja, operator atau fasilitas } \\
\text { kerja dalam keadaan berhenti / tidak ada kegiatan }\end{array}$ \\
\hline & $\begin{array}{c}\text { MENYIMPAN } \\
\text { (STORAGE) }\end{array}$ & $\begin{array}{l}\text { Kegiatan ini terjadi bila ada obyek yang disimpan dalam jangka } \\
\text { waktu yang cukup lama }\end{array}$ \\
\hline & $\begin{array}{c}\text { AKTIVITAS } \\
\text { GANDA }\end{array}$ & $\begin{array}{l}\text { Bilamana dikehendaki, untuk menunjukkan kegiatan yang } \\
\text { secara bersamaan dilakukan pada stasiun kerja yang sama }\end{array}$ \\
\hline
\end{tabular}




\section{Pengukuran Jarak}

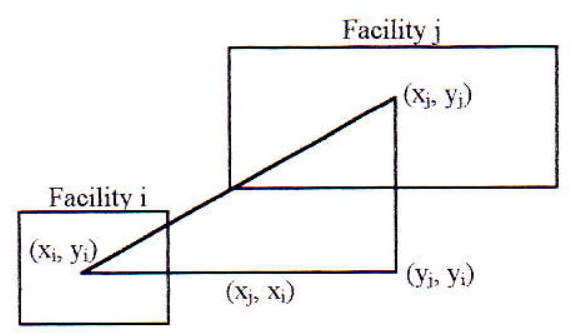

\section{Euclidean}

Matrik euclidean mengukur garis lurus antara pusat dari fasilitas-fasilitas. Matrik euclidean telah diaplikasikan untuk model konveyor dan jaringan transportasi dan distribusi. Untuk membuat persamaan matrik euclidean, dengan notasi-notasi sebagai berikut :

\section{$\mathrm{x}_{\mathrm{i}}$ : $\quad \mathrm{x}$ koordinat dari pusat fasilitas $\mathrm{i}$ \\ $\mathrm{y}_{\mathrm{i}}$ : $\quad \mathrm{y}$ koordinat dari pusat fasilitas $\mathrm{j}$ \\ $\mathrm{d}_{\mathrm{ij}} \quad$ : jarak antara pusat fasilitas $\mathrm{i}$ dan $\mathrm{j}$} jarak untuk matrik euclidean diukur dengan rumus

$$
\mathrm{d}_{\mathrm{ij}}=\left[\left\{\mathrm{x}_{\mathrm{i}}-\mathrm{x}_{\mathrm{j}}\right\}+\left\{\mathrm{y}_{\mathrm{i}}-\mathrm{y}_{\mathrm{j}}\right\}\right]^{0.5}
$$

\section{Square Euclidean}

Matrik ini digunakan pada kondisi yang memiliki jarak yang agak jauh atau jauh sekalipun antara satu fasilitas terhadap fasilitas yang lain. Matrik ini memiliki persamaan :

$$
\left.d_{i j}=\left\{x_{i}-x_{j}\right\}^{2}+\left\{y_{i}-y_{j}\right\}\right]
$$

\section{Rectilinear}

Matrik ini biasa digunakan karena lebih mudah untuk menghitungnya, mudah dimengerti dan diaplikasikan untuk masalahmasalah yang praktis. Matrik ini memiliki persamaan :

$$
d_{i j}=\left|x_{i}-x_{j}\right|^{2}+\left|y_{i}-y_{j}\right|^{2}
$$

\section{Kriteria Evaluasi Layout}

Untuk mengevaluasi layout yang diberikan, pertama kali analis harus menentukan kriteria untuk menilai layout tersebut. Dalam hal ini pengevaluasian layout berdasarkan kriteria sebagai berikut :

$$
\Sigma_{\mathrm{i}} \Sigma_{\mathrm{j}} \mathrm{c}_{\mathrm{ij}} \mathrm{f}_{\mathrm{ij}} \mathrm{d}_{\mathrm{ij}}
$$

\section{Dimana :}

$\mathrm{c}_{\mathrm{ij}}$ : biaya untuk memindahkan unit beban material dari fasilitas $\mathrm{i}$ dan $\mathrm{j}$

$f_{i j} \quad$ jumlah perjalanan antara fasilitas $i$ dan $\mathrm{j}$

$\mathrm{d}_{\mathrm{ij}} \quad$ : jarak antara fasilitas $\mathrm{i}$ dan $\mathrm{j}$

\section{METODOLOGI PENELITIAN}

\section{Data yang Diperlukan}

Adapun data yang diperlukan dalam analisa antara lain : data nama komponen yang dibuat, data permintaan actual, data proses permesinan, data alat angkut, data frekuensi perpindahan, jumlah batch size, gambar 
layout awal, biaya yang diperlukan untuk menghitung material handling

\section{Tahapan Pengolahan Data}

Tahapan-tahapan yang dilakukan dalam analisa antara lain :

1. Perhitungan jarak dan biaya material handling layout awal bagian produksi I

2. Running program gtlapc.exe berdasarkan group teknologi untuk :

* Mengelompokkan mesin menjadi machine cell dan komponen menjadi part family berdasar $R \& C M$ Algorithm

* Pembentukan layout mesin inter sell berdasar Simulated Annealing Algorithm

* Pembentukan layout mesin antar sell berdasar Hibrid Simulated Annealing Algorithm

3. Penyusunan lay out mesin baru sebagai hasil dari subyektifitas peneliti berdasarkan running program gtlapc.exe

\section{HASIL DAN PEMBAHASAN}

\section{Pengukuran Jarak Mesin}

Jarak antar mesin yang dilalui material handling per produk dihitung dengan menggunakan metode rectilinear, karena metode ini mudah diaplikasikan. Contoh pengukuran dengan metode rectilinear:

Misalnya jarak dari mesin 1 ke mesin 15

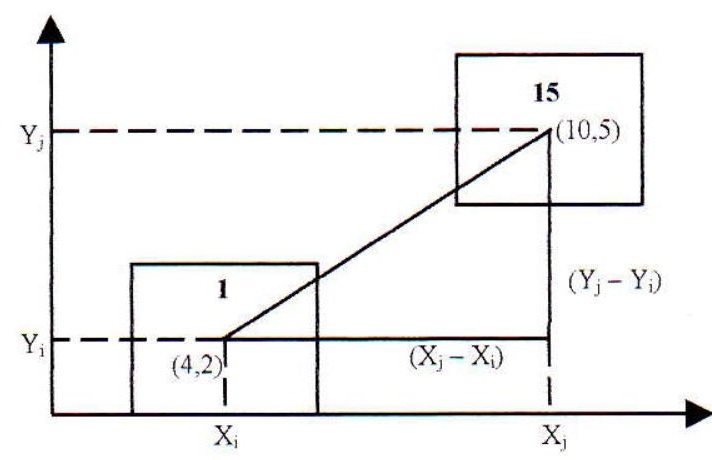

Keterangan :

1 : menunjukkan fasilitas (mesin) ke-i

15 : menunjukkan fasilitas (mesin) ke-j Jadi jarak dari $1-15=$

$$
\left|x_{i}-x_{j}\right|+\left|y_{i}-y_{j}\right|=9
$$

\section{Tabel 1}

Jarak antar Mesin Pada Proses Pemindahan Bahan Layout Awal

\begin{tabular}{|c|c|c|c|c|c|c|}
\hline \multirow{3}{*}{$\begin{array}{l}\text { Kode } \\
\text { Produk }\end{array}$} & \multirow{3}{*}{$\begin{array}{l}\text { Dari mesin i Ke } \\
\text { mesin } \mathbf{j}\end{array}$} & \multirow{2}{*}{\multicolumn{2}{|c|}{$\begin{array}{l}\text { Pada Sumbu } \\
\text { Koordinat } x\end{array}$}} & \multirow{2}{*}{\multicolumn{2}{|c|}{$\begin{array}{l}\text { Pada Sumbu } \\
\text { Koordinat y }\end{array}$}} & Metode Rectilinear (m) \\
\hline & & & & & & \\
\hline & & $\begin{array}{r}\mathbf{x}_{\mathbf{i}} \\
(\mathbf{m})\end{array}$ & $\begin{array}{c}\mathbf{x}_{\mathbf{i}} \\
(\mathbf{m})\end{array}$ & $\begin{array}{c}\mathbf{y}_{1} \\
(\mathbf{m})\end{array}$ & $\begin{array}{c}\mathbf{y}_{1} \\
(\mathbf{m})\end{array}$ & $\left|\mathrm{x}_{\mathrm{i}}-\mathrm{x}_{\mathrm{j}}\right|+\mid \mathrm{y}_{\mathrm{i}}-\mathrm{y}_{\mathrm{j}}$ \\
\hline A. & - & - & - & - & - & - \\
\hline B. & $1-15$ & 1.5 & 40 & 49 & 2.5 & 85 \\
\hline C. & $2-16$ & 1.5 & 46 & 41.5 & 2 & 84 \\
\hline D. & $2-16$ & 1.5 & 46 & 41.5 & 2 & 84 \\
\hline 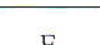 & $3-16$ & 1.5 & 46 & 36.5 & 2 & 79 \\
\hline $\mathrm{E}$. & $16-15$ & 46 & 40 & 2 & 2.5 & 6.5 \\
\hline F. & $3-14$ & 1.5 & 33.5 & 36.5 & 2.5 & 66 \\
\hline G. & $4-14$ & 1.5 & 33.5 & 31.5 & 2.5 & 61 \\
\hline $\mathrm{H}$. & $5-15$ & 1.5 & 40 & 26.5 & 2.5 & 62.5 \\
\hline I. & $4-15$ & 1.5 & 40 & 31.5 & 2.5 & 67.5 \\
\hline
\end{tabular}




\begin{tabular}{|c|c|c|c|c|c|c|}
\hline J. & $7-15$ & 2 & 40 & 16 & 2.5 & 51.5 \\
\hline K. & - & - & - & - & - & - \\
\hline L. & $8-16$ & 1.5 & 46 & 10 & 2 & 52.5 \\
\hline \multirow{2}{*}{ M. } & $9-15$ & 1 & 40 & 2.5 & 2.5 & 39 \\
& $15-16$ & 40 & 46 & 2.5 & 2 & 6.5 \\
\hline N. & $10-15$ & 7 & 40 & 1.5 & 2.5 & 34 \\
\hline O. & $15-16$ & 40 & 46 & 2.5 & 2 & 6.5 \\
\hline P. & $11-15$ & 13 & 40 & 1.5 & 2.5 & 28 \\
\hline Q. & $12-17$ & 19.5 & 52 & 2 & 4 & 34.5 \\
\hline
\end{tabular}

\section{Pengukuran Jarak Tempuh Perpindahan Bahan}

Tabel 2

Jarak Tempuh Prpindahan Bahan Layout Awal

\begin{tabular}{|c|c|c|c|c|}
\hline Kode Produk & $\begin{array}{c}\text { Dari mesin i } \\
\text { ke mesin j }\end{array}$ & $\begin{array}{c}\text { Jarak } \\
(\mathbf{m})\end{array}$ & $\begin{array}{c}\text { Frekuensi } \\
\text { Perpindahan }\end{array}$ & $\begin{array}{c}\text { Jarak Tempuh } \\
\text { (m) }\end{array}$ \\
\hline A. & 1 & - & - & - \\
\hline B. & $1-15$ & 85 & 14 & 924 \\
\hline C. & $2-16$ & 84 & 14 & 1176 \\
\hline D. & $2-16$ & 84 & 14 & 1106 \\
\hline E. & $3-16$ & 79 & 19 & 123.5 \\
\hline F. & $16-15$ & 6.5 & 14 & 924 \\
\hline G. & $3-14$ & 66 & 11 & 671 \\
\hline H. & $4-14$ & 61 & 9 & 562.5 \\
\hline I. & $5-15$ & 62.5 & 9 & 607.5 \\
\hline J. & $4-15$ & 67.5 & - & 463.5 \\
\hline K. & $7-15$ & 51.5 & 27 & 1417.5 \\
\hline L. & 5 & - & 27 & 1053 \\
\hline M. & $8-16$ & 52.5 & 33 & 214.5 \\
\hline N. & $9-15$ & 39 & 25 & 850 \\
\hline O. & $15-16$ & 6.5 & 41 & 266.5 \\
\hline P. & $10-15$ & 34 & 14 & 392 \\
\hline Q. & $15-16$ & 6.5 & 68 & 2346 \\
\hline & $11-15$ & 28 & 49 & 1323 \\
\hline & $12-17$ & 34.5 & & $\mathbf{1 5 6 1 0 . 5}$ \\
\hline
\end{tabular}

\section{Tata Letak Baru}

Dari hasil pengumpulan dan pengolahan data yang kemudian digunakan sebagai input untuk proses running dengan program gtlapc.exe dan dari hasil running program tersebut, maka didapatkan tata letak mesin baru sebagai berikut : 


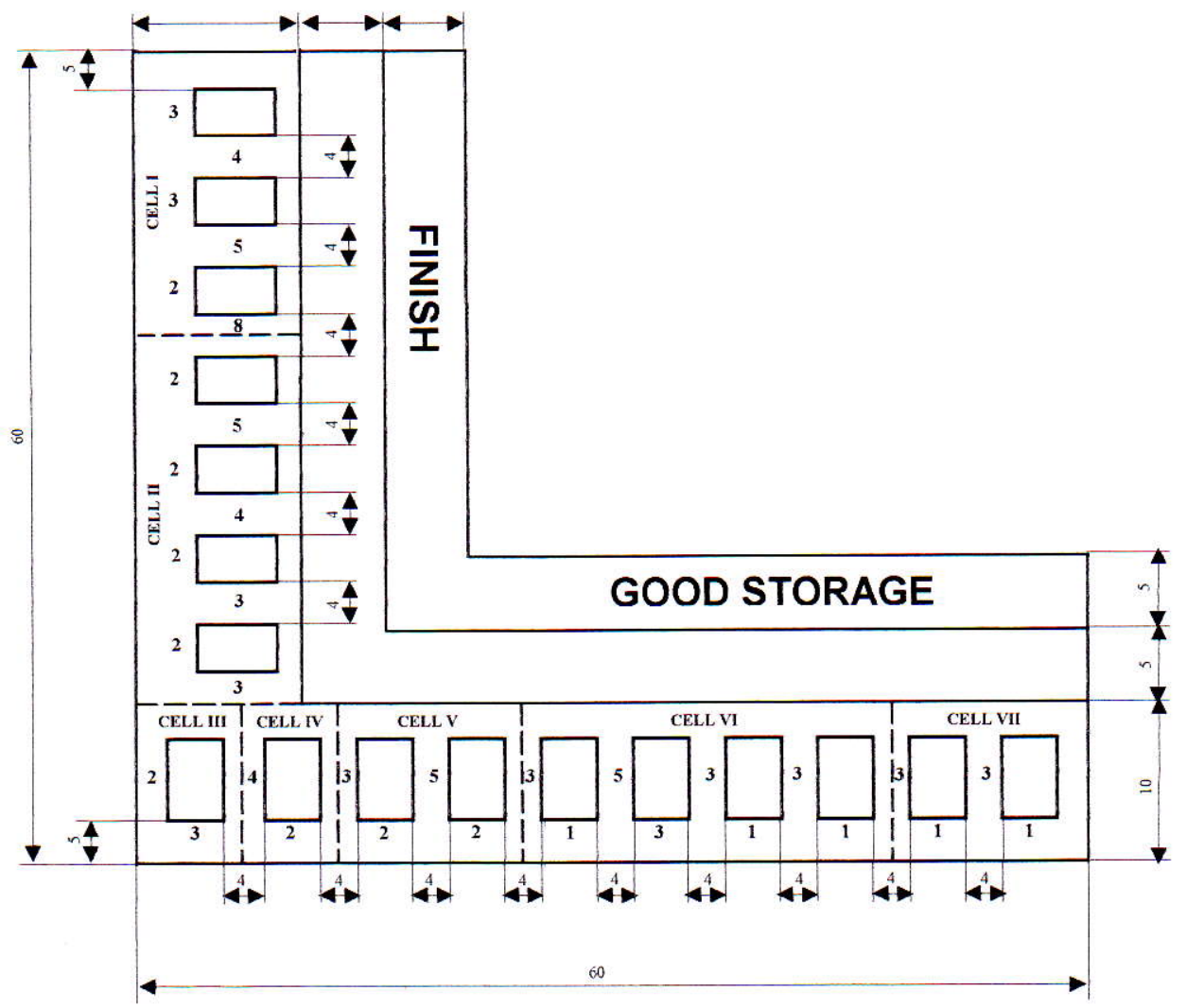

Tabel 3

Pengukuran Jarak Mesin Pada Layout Mesin Baru

\begin{tabular}{|c|c|c|c|c|c|c|}
\hline \multirow{3}{*}{$\begin{array}{c}\text { Kode } \\
\text { Produk }\end{array}$} & \multirow{3}{*}{$\underset{\text { mesin } \mathbf{j}}{\text { Dari mesin } \mathrm{Ke}}$} & \multirow{2}{*}{\multicolumn{2}{|c|}{$\begin{array}{l}\text { Pada Sumbu } \\
\text { Koordinat x }\end{array}$}} & \multirow{2}{*}{\multicolumn{2}{|c|}{$\begin{array}{l}\text { Pada Sumbu } \\
\text { Koordinat y }\end{array}$}} & \multirow{3}{*}{$\begin{array}{l}\text { Metode Rectilinear (m) } \\
\left|\mathrm{x}_{\mathrm{i}}-\mathrm{x}_{\mathrm{j}}\right|+\left|\mathrm{y}_{\mathrm{i}}-\mathrm{y}_{\mathrm{j}}\right|\end{array}$} \\
\hline & & & & & & \\
\hline & & $\begin{array}{c}\mathbf{x}_{1} \\
(\mathbf{m})\end{array}$ & $\begin{array}{c}\mathbf{x}_{\mathrm{j}} \\
(\mathbf{m})\end{array}$ & $\begin{array}{c}\mathbf{y}_{\mathbf{l}} \\
(\mathbf{m})\end{array}$ & $\begin{array}{c}\mathbf{y}_{1} \\
(\mathbf{m})\end{array}$ & \\
\hline A. & 1 & - & - & - & - & - \\
\hline B. & $1-15$ & 1 & 2.5 & 1.5 & 30 & 30 \\
\hline C. & $2-16$ & 36.5 & 2 & 1.5 & 24 & 57 \\
\hline D. & $2-16$ & 6.5 & 2 & 1.5 & 24 & 57 \\
\hline \multirow{2}{*}{ E. } & $3-16$ & 24.5 & 2 & 1.5 & 24 & 45 \\
\hline & $16-15$ & 2 & 2.5 & 24 & 30 & 6.5 \\
\hline F. & $3-14$ & 24.5 & 2 & 24 & 30 & 4 \\
\hline G. & $4-14$ & 45.5 & 2.5 & 1.5 & 2.5 & 25 \\
\hline $\mathrm{H}$. & $5-15$ & 50.5 & 21.5 & 1.5 & 2.5 & 76.5 \\
\hline I. & $4-15$ & 45.5 & 21.5 & 1.5 & 30 & 71.5 \\
\hline J. & $7-15$ & 7 & 2.5 & 1.5 & 2.5 & 32.5 \\
\hline $\mathrm{K}$. & 5 & - & - & - & - & - \\
\hline $\mathrm{L}$. & $8-16$ & 15 & 2.5 & 1.5 & 24 & 35.5 \\
\hline \multirow{2}{*}{$\mathrm{M}$} & $9-15$ & 19 & 2.5 & 2.5 & 30 & 44 \\
\hline & $15-16$ & 2.5 & 2 & 30 & 24 & 6.5 \\
\hline
\end{tabular}




\begin{tabular}{|c|c|c|c|c|c|c|}
\hline N. & $10-15$ & 1.5 & 2.5 & 12 & 30 & 19 \\
& $15-16$ & 2.5 & 2 & 30 & 24 & 6.5 \\
\hline O. & $11-15$ & 1.5 & 2.5 & 18 & 30 & 13 \\
\hline P. & $12-17$ & 2 & 4 & 49.5 & 36 & 15.5 \\
\hline Q. & $13-17$ & 2.5 & 4 & 42.5 & 36 & 8 \\
\hline
\end{tabular}

Tabel 4

Jarak Tempuh Prpindahan Bahan Layout Mesin Baru

\begin{tabular}{|c|c|c|c|c|}
\hline Kode Produk & $\begin{array}{l}\text { Dari mesin i } \\
\text { ke mesin j }\end{array}$ & $\begin{array}{c}\text { Jarak } \\
(\mathbf{m})\end{array}$ & $\begin{array}{c}\text { Frekuensi } \\
\text { Perpindahan }\end{array}$ & $\begin{array}{l}\text { Jarak Tempuh } \\
\text { (m) }\end{array}$ \\
\hline A. & 1 & - & - & - \\
\hline B. & $1-15$ & 30 & 14 & 420 \\
\hline C. & $2-16$ & 57 & 11 & 627 \\
\hline D. & $2-16$ & 57 & 14 & 798 \\
\hline \multirow{2}{*}{ E. } & $3-16$ & 45 & 14 & 630 \\
\hline & $16-15$ & 6.5 & 19 & 123.5 \\
\hline F. & $3-14$ & 4 & 14 & 56 \\
\hline G. & $4-14$ & 25 & 11 & 275 \\
\hline $\mathrm{H}$. & $5-15$ & 76.5 & 9 & 688.5 \\
\hline I. & $4-15$ & 71.5 & 9 & 643.5 \\
\hline $\mathrm{J}$ & $7-15$ & 32.5 & 9 & 292.5 \\
\hline $\mathrm{K}$. & 5 & - & - & - \\
\hline $\mathrm{L}$. & $8-16$ & 35.5 & 27 & 958.5 \\
\hline \multirow{2}{*}{ M. } & $9-15$ & 44 & 27 & 1188 \\
\hline & $15-16$ & 6.5 & 33 & 214.5 \\
\hline \multirow{2}{*}{ N. } & $10-15$ & 19 & 25 & 475 \\
\hline & $15-16$ & 6.5 & 41 & 266.5 \\
\hline $\mathrm{O}$. & $11-15$ & 13 & 14 & 182 \\
\hline P. & $12-17$ & 15.5 & 68 & 1054 \\
\hline Q. & $13-17$ & 8 & 49 & 392 \\
\hline \multicolumn{4}{|c|}{ Total Jarak Yang Ditempuh Selama I Shift } & 9284 \\
\hline
\end{tabular}

Maka perbandingan jarak tempuh tata letak mesin awal dan tata letak mesin baru adalah

\section{Tabel 5}

Perbandingan Jarak Tempuh Material Handling Per Shift

\begin{tabular}{|c|c|}
\hline $\begin{array}{c}\text { Tata Letak Mesin Awal } \\
(\mathbf{m})\end{array}$ & $\begin{array}{c}\text { Tata Letak Mesin Baru } \\
(\mathbf{m})\end{array}$ \\
\hline 15610.5 & 9284.5 \\
\hline
\end{tabular}

Tabel 6

Perbandingan Jarak Tempuh Material Handling Per Hari (3 Shift)

\begin{tabular}{|c|c|}
\hline $\begin{array}{c}\text { Tata Letak Mesin } \\
\text { Awal } \\
(\mathbf{m})\end{array}$ & $\begin{array}{c}\text { Tata Letak Mesin } \\
\text { Baru } \\
(\mathbf{m})\end{array}$ \\
\hline $15610.5 \times 3=$ & $9284.5 \times 3=$ \\
46831.5 & 27853.5 \\
\hline
\end{tabular}

Dari tabel di atas dapat diketahui bahwa setelah penerapan konsep group teknologi didapatkan penghematan jarak tempuh sebesar $6326 \mathrm{~m} / \mathrm{shift}$ atau $18978 \mathrm{~m} / \mathrm{hari}$. 


\section{Perbandingan Biaya Tata Letak Mesin} Awal dengan yang Baru

Pada perbandingan biaya material handling, maka perhitungan terhadap tata letak mesin baru berdasarkan biaya per meter per hari yang sudah diketahui pada tata letak mesin awal, yaitu sebesar Rp. 1,85/meter/hari dan tabel berikut ini adalah tabel perbandingan biaya tata letak mesin awal dengan tata letak mesin baru dalam setiap meter per harinya :

Tabel 7

Perbandingan Biaya Material Handling per Hari

\begin{tabular}{|c|c|}
\hline $\begin{array}{c}\text { Tata Letak Mesin Awal } \\
(\mathbf{R p})\end{array}$ & $\begin{array}{c}\text { Tata Letak Mesin Baru } \\
(\mathbf{R p})\end{array}$ \\
\hline Rp. $1,85 \times 46831.5=$ Rp. 86638,275 & Rp. $1,85 \times 27853.5=$ Rp. 51528,975 \\
\hline
\end{tabular}

\section{KESIMPULAN}

Kesimpulan yang dapat diambil dari hasil analisa antara lain :

1. Dengan running program gtlaypc.exe berdasarkan konsep group technology, akan terbentuk pengelompokan produk menjadi 7 part family serta pengelompokan mesin menjadi 7 machine cell.

2. Hasil dari rancangan layout baru terhitung memiliki jarak dan biaya material handling $59.48 \%$ lebih minimal dibandingkan dengan layout awal.

\section{DAFTAR PUSTAKA}

Apple James M., 1977, Plant Layout and Material Handling, edisi ketiga, John Wiley \& Sons.

James A. Tompkins and John A. White, 1996, Facilities Planning, edisi kedua, John Wiley \& Sons, Canada.
James M. Moore, 1962, Plant Layout and Design, New York

Kusiak \& S.S. Heragu, 1987, “The Facility Layout Problem”, Europen Journal of Operation Research, vol.. 29.

Richards L. Francis and John A. White, 1974, Facility Layout and Location An Analytical Approach, Prentice Hall International, New Jersey.

Sritomo Wignjosoebroto, 1996 , “ Tata Letak Pabrik dan Pemindahan Bahan", edisi ketiga, PT. Guna Widya, Jakarta.

Sunderesh Heragu, 1997Facilities Design, edisi satu, PWS Publishing Company.

Yavus A. Bozer, Russell D. Meller, 1994 , "An Improvement Type Layout Algorithm For Single And Multiple Floor Facilities ", Management Science, vol 40 no 7 . 